
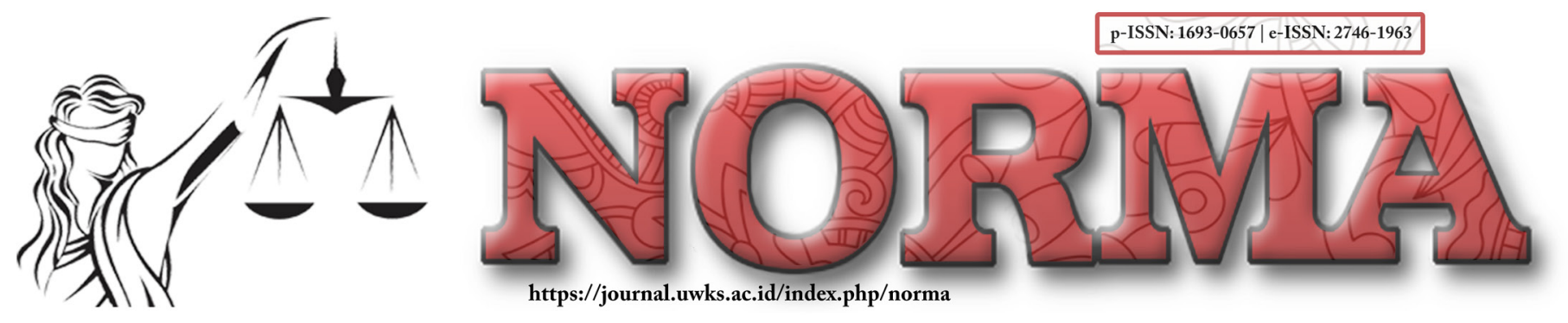

\title{
Legal Protection of Franchisee in Franchise Contract Which Franchisor Unilaterally Terminates
}

\author{
Retno Wulandari \\ Legal Auditor at H2L Advocates Law Firm \\ e-Mail: s1retnow@gmail.com
}

\begin{abstract}
:
The Franchisor and the Franchisee's engagement tends to be based on the value of business profits alone. The document that becomes evidence (franchise agreement) tends to be poorly understood by the Franchisee, which can cause legal problems for him. One of the legal issues that can occur is the unilateral termination of the Franchisor to the Franchisee. Franchise agreements tend to be standardized, which comes from the Franchisor. These conditions make the Franchisee obliged to understand the agreement's contents well so that the franchise agreement is not terminated unilaterally by the Franchisor. This study aims to find out and analyze how legal protection for franchisee is based on franchise agreement. This research method is a normative legal research approach. The result of this study is unilateral termination of the franchise agreement will undoubtedly cause various legal problems for the parties bound in the franchise agreement.
\end{abstract}

Keywords: Termination; Agreement; Franchise.

Article's History:

Received:

February 16, 2021;

Peer-Reviewed:

February 24, 2021;

Accepted:

February 27, 2021;

Published:

March 5, 2021.

DOI:

10.30742/nlj.v18i1.1288

\section{INTRODUCTION}

The increasing globalization era has opened the broadest possible opportunity for the trading system, both from the country and abroad. One form of cooperation system that is increasing in Indonesia is a form of cooperation in a franchise business. This is because Franchising is the most profitable business to develop the business world. Besides, Franchising is an improvement of the business development system that uses direct investment. With this franchise system, there will be savings in investment costs required to establish and maintain an extensive distribution network. This savings is due to the distribution network that will occur independently of the increasing number of franchisees and franchisors.

Franchising is described as a mix of "big" and "small" businesses, namely a combination of energy and individual commitment with a large company's resources and strengths. Franchising is a business arrangement in which a company (Franchisor) gives the right to an independent party (Franchisee) to sell its products or services with the Franchisor's rules. Franchisees use the name, goodwill, products and services, 
marketing procedures, expertise, operational procedure systems, and the franchisor company's supporting facilities. In return, the Franchisee pays an initial fee and royalties (management service fee) to the franchisor company as stipulated in the franchise contract.

The franchise contract is an aspect of legal protection for parties from actions that harm other parties. If one party violates the franchise contract's contents, the other party can sue the violating party following applicable law. Currently, the franchise business sector is very diverse. It is dominated by the food sector and the education, salon, retail, laundry, fitness, car wash, and vehicle accessories sectors that have been franchised.

The law that first contained the word Franchise was Law Number 9 of 1995 concerning Small Business, namely in Article 27 letter d. This law has been repealed and replaced by Law Number 20 of 2008 concerning Micro, Small and Medium Enterprises, where the word Franchise in this law is contained in Article 26 letter C, which states: "the partnership is carried out with the pattern:

a. Nucleus-plasma;

b. Subcontract;

c. Franchise;

d. General trading;

d. Distribution and agency;

e. Other forms of partnerships, such as profit sharing, operational cooperation, joint ventures, and outsourcing.

Law Number 5, the Year 1999 concerning Prohibition of Monopolistic Practices and Unfair Business Competition also mentions explicitly "Agreements relating to Franchising," namely Article 50 letter b.

The two laws above do not formulate/contain the definition of Franchising, only in Government Regulation Number 16 of 1997 concerning "Franchising" (from now on written PP. No. 16/1997), the definition of Franchising is formulated in Article 1 point 1 , as follows: "Franchising is an agreement in which one of the parties is given the right to utilize and/or use intellectual property rights or inventions or business characteristics owned by the other party for a fee based on the conditions set by the other party, in the framework of providing and or sale of goods and or services."

PP No. 16/1997 was later replaced by Government Regulation No. 42 of 2007 (from now on, written PP No. 42/2007) concerning "Franchising." It should be noted the definition of Franchising in PP. 16/1997 and the Regulation of the Minister of Trade Number 12/M-DAG/PER/3/2006 concerning the Provisions and Procedures for the Issuance of Franchise Business Registration Certificates (STPUW) changed again with the issuance of PP No. 42/2007, Article 1 point 1 states as follows: "Franchising is a special right owned by an individual or a business entity against a business 
system with business characteristics to market goods and/or services that have been proven successful and can be utilized and/or used by other parties based on a franchise agreement." From the definition of Franchise according to PP. 42/2007 above, there are 2 (two) things become key points or concerns, namely: special rights and characteristics of the business. PP No. 42/2007 itself does not explain what is meant by these individual rights. In the author's opinion, this special right is closely related to registered intellectual property rights owned by the Franchisor and then given to the Franchisee to be "used and/or used" limited to a contractual relationship in the franchise agreement. While the business's characteristics in the explanation of Article 3 PP No. 42/2007 explain a company that has advantages or differences that are not easily imitated compared to other similar businesses, and makes consumers always look for those characteristics. For example, the management system, the way of sales and service, or the arrangement or distribution method is a particular characteristic of the Franchisor.

From the definition of Franchising above, then a franchise contract contains a set of terms, conditions, and commitments made and desired by the Franchisor for the franchisees. The franchise contract includes provisions relating to the rights and obligations of the Franchisor and the recipient of the Franchise, for example, the territorial rights of the Franchisee, location requirements, training provisions, fees that the Franchisee must pay to the Franchisor, provisions relating to the length of the franchise agreement and its extension and other conditions governing the relationship between them.

Franchise agreements always vary. From an arrangement point of view, there is a variety of creativity and personal styles. ${ }^{1}$ The preparation of a franchise agreement must begin with an understanding of both parties. After that review of competing franchise agreements, an awareness of the various approaches and the need for the relationship between law and Franchising will go a long way in preparing a franchise agreement. In other words, a clear and logical writing style and lots of reviews for improvement. Franchise agreement drafting is the creation of a contract drawn up by the Franchisor and the client. Although the Franchise has been so developed in Indonesia, this business's ins and outs, including legal protection, especially for the franchise buyer are still minimal. Knowledge and education are also even minimal; this is all because franchise business players prioritize the element of business profit.

\section{RESEARCH METHOD}

This research is a normative study, which means that this research examines the legislation's side, not reading social symptoms due to existing legislation. This

1 Kim Lambert \& Todd Leff Pitegoff Thomas, Drafting Effective Franchise Agreements (New York: ABA, 2000) 5. 
research's approach method is a statutory approach (statute approach) and conceptual approach. This approach is used because the discussion in this study will refer to the Law and the concept related to the issue.

\section{DISCUSSION}

Franchising was popularized in the United States, but Franchise's origin came from Europe, namely France and England. The word Franchise or Franchise itself means "freedom" (Freedom). At that time, the nobility was given authority by the king to become landlords in certain areas. In this area, the aristocrat can take advantage of the land he controls in exchange for taxes/tribute returned to the kingdom. The system resembles royalty, much like the Franchising it is today. Another formula says the franchise agreement is an agreement in which the Franchisor sells products or services following the Franchisor's methods and procedures, which helps through advertising, promotions, and other advisory services. ${ }^{2}$

According to the perspective of Burgerlijk Wetboek (from now on referred to as BW) contained in Book III, Franchising is included in an innominate agreement or anonymous agreement that is not explicitly regulated in BW. Franchising, like a license, is a form of understanding, the contents of which give special rights and authorities to the Franchisee, which can be in the form of: ${ }^{3}$

a. The right to sell products in the form of goods and or services using specific trade names or trademarks;

b. The right to carry out business activities with or based on a business format determined by the Franchisor. According to the concept of civil law, it is explicitly said because the franchise agreement is a special agreement because it is not found in the Burgerlijk Wetboek (BW). The franchise agreement is accepted and recognized as an agreement based on the principle of freedom of contract as stated in the provisions of Article 1338 BW.

The franchise agreement is generally in a standardized format by the Franchisor, which creates an unbalanced position for the Franchisee, but that does not mean reducing the meaning of the freedom of contract itself. This standardized contract form is often referred to as a standard contract or standard contract, namely an agreement whose contents have been predetermined in writing in the form of an unlimited number of duplicated documents to be offered to consumers regardless of differences in the conditions of the consumers. Therefore, consumers must understand the agreement's contents to avoid legal problems, one of which is the contract's unilateral termination.

Unilateral termination of the Franchisor's agreement or contract is undoubtedly

2 Johannes Ibrahim, Hukum Bisnis Dalam Persepsi Manusia Modern (Bandung: Rafika Aditama, 2004) 134 .

3 Amir Karamoy, Waralaba - Jalur Bebas Hambatan Menjadi Pengusaha Sukses (Jakarta: Raja Grafindo Persada, 2013) 40. 
very detrimental to the Franchisee, so it does not rule out the Franchisee to claim compensation for the losses he has suffered. If the Franchisee demands payment, then the Franchisor must pay the loss if it is proven that the Franchisor is guilty of making a unilateral termination. Conversely, if the Franchisee causes the default or negligence, the Franchisor can also claim compensation. Before stating that one of the parties is in default, either by the Franchisor or the Franchisee, the parties resolve the dispute by deliberation first by giving a warning. ${ }^{4}$

Furthermore, the aggrieved party can sue in one of the ways mentioned in Article $1267 \mathrm{BW}$ if the summons is ignored, among others, by fulfilling the engagement, fulfilling the agreement with compensation, claiming compensation, canceling the mutual understanding, and canceling the payment. ${ }^{5}$

Based on the facts in several franchise agreements, there are many disputes between the Franchisor and the Franchisee in many cases, even on "trivial" matters, for example, the Franchisee's obligation to buy certain ingredients or seasonings from the region/country. The Franchisor, even though the ingredients/spices also exist in Indonesia or the franchise recipient area. This is a separate burden for the Franchisee, especially regarding other costs that must be incurred and royalty fees, and so on, including the time of service.

Another problem, namely, the Franchisor's training and development to the Franchisee, is not optimal, often resulting in the sale of the franchise product purchased. This also results in obstruction of the payment of royalties to the Franchisor. This happens specially to franchise businesses that are already well known globally (wellknown trademarks), such as McDonald's, Kentucky Fried Chicken, Pizza Hut, etc. If there is a business dispute between them, it is very rarely brought into the realm of litigation (court). They tend to take their disputes to the realm of Arbitration.

Dispute resolution through Arbitration is an alternative. Law No. 30 of 1999 concerning Arbitration and Alternative Dispute Resolution states that Arbitration is "settlement of civil disputes outside the court of law based on an arbitration agreement made in writing by the disputing parties." ${ }^{6}$ Arbitration as an alternative to dispute resolution has several advantages, including:

a. The trial process is closed to the public; this is solely for the sake of maintaining the confidentiality of business matters between the disputing parties;

b. The trial process is relatively short, in which the processing period from the start of the examination to the verdict is 30 (thirty) days; and

c. The Arbitration Award is final and binding; there is no further legal remedy for the arbitration award.

4 R Setiawan, Pokok-Pokok Hukum Perikatan (Bandung: Bina Cipta, 1999) 21.

5 Ibid., 25.

6 Gunawan Widjaja and Kartini Muljadi, Seri Hukum Bisnis: Alternatif Penyelesaian Sengketa (Jakarta: Raja Grafindo Persada, 2001) 55. 
As a comparison, one example of terminating a franchise agreement in Indonesia is the dispute between Beauty Salon De Grace (the Franchisor) and the Beauty and Slimming Salon "Yemember" (the Franchisee). The dispute termination of this agreement is included in the domain of Arbitration through the case register number: No.31/ARB/BANI-SBY/1/2012, where the Beauty and Slimming Salon "Yemember" (Thio Inge Catherine's mother as the Franchisee) cannot fulfill the agreement has been mutually agreed (default).

The decision of the Arbitrator Council of the Indonesian National Arbitration Board for the city of Surabaya on decision No.31/ARB/BANI-SBY/1/2012 on cases filed by parties in good standing by Thio Inge Catherine (Franchisee) and Naniek Soetrisno (Franchisor), the ruling stated that:

a. To partially grant the petition submitted by the Petitioner;

b. Declare that the Franchise Cooperation Agreement contained in the Deed No. 34 drawn up before the Notary Natalya Yahya Puteri Wijaya, SH dated 31 August 2010 ended and no longer bound the Petitioner and the Respondent;

c. To punish the Petitioner and the Respondent to pay half of the case fees and because the Petitioner has paid the court fees, which are the responsibility of the Respondent, the Respondent is punished for returning the cost of this case to the Petitioner, which is Rp. 13,555,000, - (thirteen million five hundred and fifty-five thousand rupiahs);

d. Ordered the Secretary of the Assembly to officially register the decision at the Registrar's Office of the Surabaya District Court at the Petitioner and Respondent's expense, within the grace period as stipulated in the law.

The arbitrator panel concluded that the Respondent (Franchisee) has defaulted through its legal considerations, it is appropriate to accept the legal consequences. In this case, the legal matters if one of the parties has defaulted, namely referring to Article $1266 \mathrm{BW}$, which regulates that "If one of the parties is not fulfilling its obligations/ default, the agreement can be canceled, "and Article 1267 BW states:" The party to which the engagement is not fulfilled, can choose whether if it can still be done, will force the other party to comply with the agreement, or will demand cancellation of the deal, accompanied by reimbursement of fees, losses, and interest. One important legal principles is the privity of contract, where the agreement must provide legal protection to those bound in it. ${ }^{7}$

The Government has been very concerned about various phenomena and different business models in society, especially this franchise business. Therefore, multiple regulations of the minister of trade as part of the implementing rules of Government Regulation Number 42 of 2007 have been published, including:

7 Agus Yudha Hernoko, Hukum Perjanjian: Asas Proporsionalitas Dalam Kontrak Komersil (Jakarta: Prenada Media Group, 2011) 33. 
a. Minister of Trade Regulation No. 12/M-DAG/PER/3/2006 concerning Provisions and Procedures for Issuance of Franchise Business Registration Certificate;

b. Minister of Trade Regulation No. 68/M-DAG/PER/10/2012 concerning Franchising for Modern Store Business Types;

c. Minister of Trade Regulation No. 07/M-DAG/PER/2/2013 concerning Development of Partnerships in Franchising for Food and Drinking Service Business Types;

d. Minister of Trade Regulation No. 56/M-DAG/PER/9/2014 concerning Amendments to the Regulation of the Minister of Trade No. 70/M-DAG/PER/12/2013 concerning Guidelines for the Arrangement and Development of Traditional Markets, Shopping Centers and Modern Stores;

e. Minister of Trade Regulation No. 57/M-DAG/PER/9/2014 concerning Amendments to the Regulation of the Minister of Trade No. 53/M-DAG/PER/8/2012 concerning Franchising; and

f. Minister of Trade Regulation No. 60/M-DAG/PER/9/2013 regarding Franchise Logo.

This is an attempt by the Government to provide legal protection externally for "business players" in this field. The essential obligations up to the procedures for treating the franchise business that must be fulfilled both for the Franchisor and the Franchisee have been regulated in detail, even if there are restrictions on outlets (branches) in the franchise business (maximum 250 outlets) have also been regulated. It can also be used to protect new franchisors so that they are motivated to develop new franchise business models, also to avoid unfair business competition.

Article 6 Permendagri No. 56/M-DAG/PER/9/2014 has confirmed that in implementing the franchise agreement that has been made, both the Franchisor and the Franchisee must comply with the provisions of laws and regulations related to their business activities, including laws and regulations in the field of consumer protection. Health, education, environment, spatial planning and labor, intellectual property rights following the prevailing laws and regulations.

Based on this, in the end, we will understand that a good agreement is an agreement that can provide legal protection to all parties who make and sign the deal and can maintain trust so that in the end, they can minimize the occurrence of disputes in the future. A well-laid-out agreement will provide legal protection internally for the franchise business.

\section{CLOSING}

\section{Conclusion}

Unilateral termination of the franchise agreement will undoubtedly cause various legal problems for the parties bound in the franchise agreement. There are 
also several dispute resolutions options between them, both in litigation (through the court's realm) and non-litigation, including mediation, negotiation, and Arbitration. A good agreement can also provide good internal legal protection to the parties who make it because it can prevent the parties from disputes that occur at a later date. Furthermore, external protection is obtained from the laws and regulations governing the terms of the Franchise itself.

\section{Recommendation}

Good legal protection starts early, meaning from the pre-contractual stage to pouring an agreement on the parties' rights and obligations (the Franchisee and recipient) in a franchise agreement really must be based on good spirit and good faith. Furthermore, from the foundation of good faith and consistency of the parties' compliance with the implementation of the rights and obligations of the franchise agreement, it is hoped that it will prevent the parties from arising business disputes or disputes between them. Only with this, trust will continue to be built and maintained; therefore, business contracts, especially franchise agreements, must be well and meticulously arranged. The possibilities that occur in the business contract to minimize the risk of his clients.

\section{REFERENCES}

Hernoko, Agus Yudha. Hukum Perjanjian: Asas Proporsionalitas Dalam Kontrak Komersil. Jakarta: Prenada Media Group, 2011.

Ibrahim, Johannes. Hukum Bisnis Dalam Persepsi Manusia Modern. Bandung: Rafika Aditama, 2004.

Karamoy, Amir. Waralaba - Jalur Bebas Hambatan Menjadi Pengusaha Sukses. Jakarta: Raja Grafindo Persada, 2013.

Pitegoff Thomas, Kim Lambert \& Todd Leff. Drafting Effective Franchise Agreements. New York: ABA, 2000.

Setiawan, R. Pokok-Pokok Hukum Perikatan. Bandung: Bina Cipta, 1999.

Widjaja, Gunawan, and Kartini Muljadi. Seri Hukum Bisnis: Alternatif Penyelesaian Sengketa. Jakarta: Raja Grafindo Persada, 2001. 